\title{
Interdisciplinarity in Education: Overcoming Fragmentation in the Teaching-Learning Process
}

\author{
Carla Madalena Santos ${ }^{1}$, Rubia Amanda Franco ${ }^{1}$, Diego Leon ${ }^{1}$, Daniel Bovolenta Ovigli ${ }^{2} \&$ Pedro Donizete \\ Colombo Júnior ${ }^{2}$ \\ ${ }^{1}$ Postgraduate program in education, Federal University of Triângulo Mineiro (UFTM), Minas Gerais, Brazil \\ ${ }^{2}$ Professor, Federal University of Triângulo Mineiro (UFTM), Minas Gerais, Brazil \\ Correspondence: Pedro Donizete Colombo Júnior, Federal University of Triângulo Mineiro (UFTM). Institute of \\ Mathematics, Natural Sciences and Education (ICENE), Avenue Dr. Randolfo Borges Junior, $\mathrm{n}^{\circ} 1.250$, ZIP Code: \\ 38064-200, Uberaba, Minas Gerais, Brazil. Tel: 55-34-3331-3146. E-mail: pedro.colombo@uftm.edu.br
}

Received: May 8, 2017 Accepted: June 24, $2017 \quad$ Online Published: September 28, 2017

doi:10.5539/ies.v10n10p71 URL: https://doi.org/10.5539/ies.v10n10p71

\begin{abstract}
The importance of interdisciplinarity in the teaching-learning process has been much debated. This topic has challenged schoolteachers, who do not always manage to integrate interdisciplinarity into the school routine. This paper emerged from the discipline Research Methodology taught at the postgraduate course in education of Universidade Federal do Triângulo Mineiro. During this course, we sought to gain knowledge about the academic production related to interdisciplinarity in the teaching-learning process, mainly in terms of teacher training and teaching practice, published in dissertations and theses. We explored contents published from 2011 to 2016 in Brazil. The covered period was based on a search for recent productions on the proposed theme, conducted by using the database of the Brazilian Digital Library of Theses and Dissertations. Analyses of the documents pointed to the need to work interdisciplinarity during teacher training courses and to adopt an interdisciplinary posture in daily teaching practice in schools. These practices should help to overcome compartmentalization of the teaching-learning process and to provide students with a global view of the world.
\end{abstract}

Keywords: teaching practice, interdisciplinarity, education

\section{Introduction}

Considering that we live in an ever-changing society, schools must provide learners with the means to exert their autonomy, to exercise their citizenship, and to develop their creativity. Nevertheless, according to Rocha Filho, Borges \& Basso (2007), deficient training has traditionally led teachers in Brazil to act on behalf of educational policies. In their daily routine, teachers face difficulties originating from a fragmented teaching-learning process, a phenomenon that fails to meet the demands of the modern society (Lück, 1997; Paviani, 2008). These difficulties stem from the way that knowledge is currently organized into disciplines. The present organization confers rigidity, artificiality, and false autonomy to the disciplines, preventing changes to the pedagogical process and to the production of new knowledge (Paviani, 2008).

In this context, the need to overcome fragmented teaching and to promote a global view of the world calls for an interdisciplinary teaching-learning process. To achieve this objective, teachers must have access to interdisciplinarity during their training, which should contribute to their adopting an interdisciplinary posture that will foster changes in their teaching practice and which will make their work more productive.

In Fazenda's view, introducing interdisciplinarity in the classroom implies that pedagogy be deeply transformed to promote the formation of a new kind of teachers that teach in a different way:

One goes from a pedagogical relationship based on a discipline or subject matter, established according to a linear hierarchical model, to a dialogic relationship where everybody has the same position. In this context, the teacher acts as a critic and moderator by excellence (Fazenda, 1979, pp. 48-49).

Interdisciplinarity seeks to go beyond the limits of school disciplines and of the many areas of knowledge, to promote more effective learning. It aims to transform how science is produced and reality is perceived (Paviani, 2008). Bearing these considerations in mind and taking the need to review the academic production on this 
theme into account, this work has focused on the academic production related to interdisciplinarity in the teaching-learning process, mainly in terms of teacher training and teaching practice, published in dissertations and theses between 2011 and 2016 .

\section{Fragmented Teaching-Learning Process and Interdisciplinarity}

The current design of the school curriculum generally reinforces the delivery of fragmented contents of the different areas of knowledge, a consequence of overspecialization. According to Gerhard \& Rocha Filho (2012, p. 127), "knowledge is separated into relatively compartmented contents even in the context of a given discipline, and the contents are presented in a dissociated and disconnected fashion".

In Paviani's (2008) opinion, disciplines are logical and political arrangements. Considering that a single human being cannot hold all types of knowledge, organization of knowledge into disciplines has been adopted to gain detailed expertise. However, this strategy has culminated in a fragmented teaching-learning process that fails to stimulate critical thinking and intellectual curiosity (Santomé, 1998).

To expand this discussion, Lück states that:

In an attempt to make students learn, teachers give importance to the content itself and not to its relation with the situation from which it emerges, generating the classic dissociation between theory and practice: what is learnt does not correspond to the reality (Lück, 1997, p. 21).

Still according to Paviani (2008, p. 14), interdisciplinarity emerges as "a symptom of the crisis of disciplines, of excess and fragmented knowledge, and of specialization, at the expense of a global view". In the Brazilian scenario, documents that guide basic education include contextualization and interdisciplinarity as basic components of the educational process.

When we attempt to define interdisciplinarity, we realize that a straightforward definition of the term does not exist because a scope of explanations translates it, which makes interdisciplinarity polysemous. The various meanings of interdisciplinarity stem from

indiscriminate use of the term in teaching, research, professional practice, media, congresses and seminars, and scientific literature headings, which points to multiple meanings and to the consequent lack of a precise meaning that is accepted by the teaching and research community (Paviani, 2008, p. 14).

Fazenda (2008, p. 17) considers that interdisciplinarity is a "bold attitude and search for knowledge". Gadotti (1999, p. 2) highlights: "Interdisciplinarity aims to ensure the construction of holistic knowledge, breaking the boundaries of disciplines". Japiassu (1976) defends the notion that interdisciplinarity is characterized by the intensity of the exchange between specialists and by the actual degree of integration of disciplines within the same project. According to Japiassu (1976), when we divide sciences into multiple specialities, we end up producing a "pathological state" of knowledge, characterized by excess specialization. According to Brazilian official documents,

interdisciplinarity does not dilute disciplines; indeed, it maintains their individuality while integrating them through comprehension of the multiple causes or factors that impact the reality. Interdisciplinarity deals with all the languages that are necessary to build knowledge, to communicate, to negotiate meanings, and to record results systematically (Brazil, 2000, p. 76).

To experience interdisciplinarity, it is necessary to know it, to research it, and to define what we intend to do with it while respecting the distinction between training "by" interdisciplinarity and training "for" interdisciplinarity, as noted by Fazenda (1979). We can still view interdisciplinarity as an open posture to knowledge, through which we favor meeting with new ideas while revisiting old ideas.

Interdisciplinarity is perceived as challenging and enjoyable to those that incorporate it into their teaching practice. Trindade (2008) considers five principles that lead professionals to reflect about interdisciplinarity in the school context and to attempt better comprehension of the reality. The principles are i) being humble and accepting the limits of our knowledge (albeit this should not be a limiting factor); ii) practicing what is preached; iii) waiting for the new to emerge; iv) viewing old knowledge as new knowledge; and v) exercising detachment.

\section{Methodological Path}

This is a qualitative and quantitative exploratory review of teaching methodologies published in the literature. We have used research theses and dissertations recorded in the database of the Brazilian Digital Library of Theses and Dissertations (BDTD, 2016). In the first stage of this work, we searched the aforementioned database for productions within the scope of our investigation. We initiated the searches by using the word 
"interdisciplinarity" and then "education", followed by the period spanning from 2011 to 2016. Next, we read and re-read the abstracts to select the theses and dissertations that focused on teacher training and interdisciplinary practice.

Our next step was to localize the studies we selected by using databases to access theses and dissertations of postgraduate programs in Brazil. We read all the selected publications and filed them by recording information such as the title of the thesis/dissertation; the author of the thesis-dissertation; the author's academic title, institution, research line, and advisor; the year of conclusion; and keywords.

Next, we qualitatively and quantitatively analyzed the selected materials by focusing on their themes. We paid attention to research trends and/or topics, investigative issues, objectives, theoretical references, methodologies and methodological procedures, target subjects and contexts, data analyses, main results, and considerations. We summarized these elements in a descriptive table and indicated the percentage of papers that mentioned interdisciplinarity approaches.

\section{Results and Discussion}

We located 1,359 works related to interdisciplinarity from 2011 to 2016. A search that included the keywords interdisciplinarity and education retrieved 65 items, 50 (77\%) MSc dissertations and $15(23 \%) \mathrm{PhD}$ theses. After definition of the period (from 2011 and 2016), 40 results (Table 1) were retrieved, namely 28 (70\%) MSc dissertations and $12(30 \%) \mathrm{PhD}$ theses.

Table 1. Distribution of productions between 2011 and 2016

\begin{tabular}{lccccccc}
\hline Year & 2011 & 2012 & 2013 & 2014 & 2015 & 2016 & Total \\
\hline Number of dissertations and theses & 7 & 9 & 8 & 8 & 7 & 1 & 40 \\
Percentage (\%) & 17.5 & 22.5 & 20 & 20 & 17.5 & 2.5 & 100 \\
\hline
\end{tabular}

Despite the retrieval of a large number of works related to interdisciplinarity in education along the target period, only four dissertations and one thesis $(12.5 \%)$ were in line with our objectives. This evidences the scarcity of productions on this issue. The Figure 1 illustrates the focus and subcategories of the 40 publications retrieved from the database of the Brazilian Digital Library of Theses and Dissertations (2011-2016).

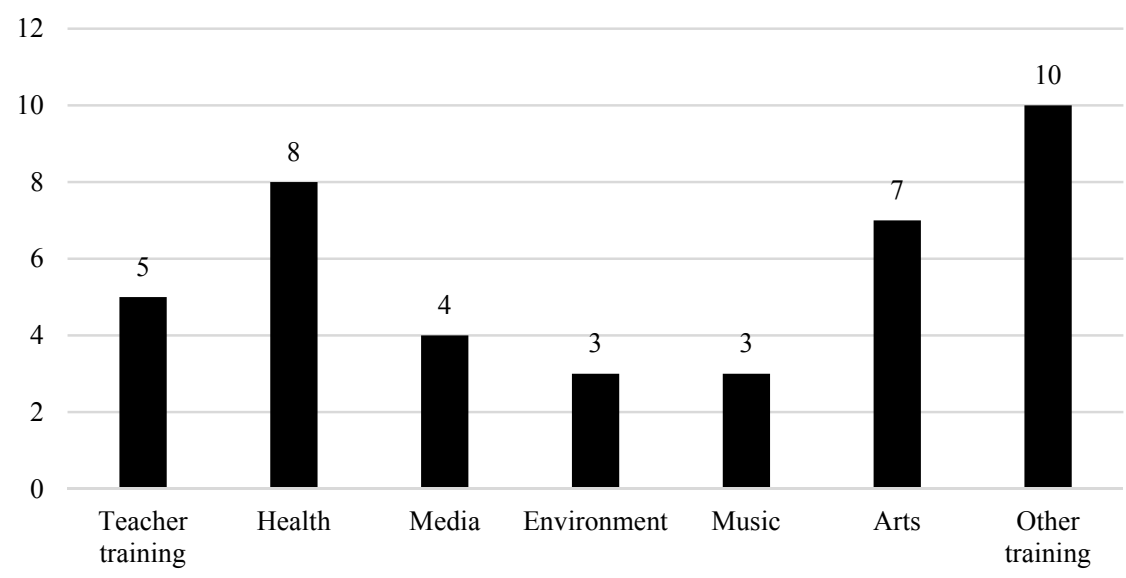

Figure 1. Quantitative subcategorization of the studies on interdisciplinarity and education.

Of all the publications on interdisciplinarity, ten (25\%) dealt with training in areas that did not concern teaching (dentistry, design, management, administration, and others). Eight publications $(20 \%)$ were in the area of health, especially nutrition. Three publications (7.5\%) focused on interdisciplinarity and the environment. Other three publications (7.5\%) highlighted the importance of working with music. Four publications (10\%) regarded interdisciplinarity and media. Seven publications (17.5\%) related interdisciplinarity to art. Only five publications $(12.5 \%)$ tackled teacher training and interdisciplinary practice, as listed in Table 2. 
Table 2. Selection of works according to the keywords searched in BDTD

\begin{tabular}{|c|c|c|c|c|c|}
\hline Work & Author & Institution & Year & Keywords & Type \\
\hline $\begin{array}{l}\text { T1 } \\
\text { Development of teachers' } \\
\text { understanding of interdisciplinarity in } \\
\text { teacher training courses: Constructing } \\
\text { meanings and senses }\end{array}$ & $\begin{array}{l}\text { Ludmila de } \\
\text { Almeida } \\
\text { Freire }\end{array}$ & $\begin{array}{c}\text { Universidade } \\
\text { Federal do Ceará }\end{array}$ & 2011 & $\begin{array}{l}\text { Interdisciplinarity } \\
\text { Rationality of the } \\
\text { communicative action } \\
\text { Teacher training }\end{array}$ & Dissertation \\
\hline $\begin{array}{l}\mathrm{T} 2 \\
\text { Interdisciplinarity in the context of a } \\
\text { pedagogy course: Pertinence of } \\
\text { conceptions and didactic-pedagogical } \\
\text { conceptions }\end{array}$ & $\begin{array}{c}\text { Emília Karla } \\
\text { de Amaral } \\
\text { Pignata }\end{array}$ & $\begin{array}{l}\text { Universidade } \\
\text { Católica de } \\
\text { Brasilia }\end{array}$ & 2011 & $\begin{array}{l}\text { Interdisciplinarity } \\
\text { Pedagogy } \\
\text { Conception } \\
\text { Didactic-pedagogical } \\
\text { actions }\end{array}$ & Dissertation \\
\hline $\begin{array}{l}\text { T3 } \\
\text { Dissertations focusing on } \\
\text { interdisciplinarity in postgraduate } \\
\text { programs in education and sciences } \\
\text { and mathematics of the Pontifical } \\
\text { Catholic University of Rio de Janeiro: } \\
\text { Theory-practice relations }\end{array}$ & $\begin{array}{c}\text { Elise Oliveira } \\
\text { Cordeiro }\end{array}$ & $\begin{array}{c}\text { Pontificia } \\
\text { Universidade } \\
\text { Católica do Rio } \\
\text { Grande do Sul }\end{array}$ & 2012 & ----- & Dissertation \\
\hline $\begin{array}{l}\text { T4 } \\
\text { Teacher's interdisciplinary posture and } \\
\text { human development: Focus on a } \\
\text { public High School }\end{array}$ & $\begin{array}{l}\text { Daniel de } \\
\text { Carvalho } \\
\text { Costa }\end{array}$ & $\begin{array}{c}\text { Universidade de } \\
\text { Taubaté }\end{array}$ & 2012 & $\begin{array}{l}\text { Human development } \\
\text { Interdisciplinarity } \\
\text { Interdisciplinary posture }\end{array}$ & Dissertation \\
\hline $\begin{array}{l}\text { T5 } \\
\text { School interdisciplinarity: A possible } \\
\text { path }\end{array}$ & $\begin{array}{l}\text { Odoaldo Ivo } \\
\text { Rochefort } \\
\text { Neto }\end{array}$ & $\begin{array}{l}\text { Universidade } \\
\text { Federal do Rio } \\
\text { Grande do Sul }\end{array}$ & 2013 & $\begin{array}{c}\text { Interdisciplinarity } \\
\text { Pedagogical practices } \\
\text { Curricular parameters } \\
\text { High School }\end{array}$ & Thesis \\
\hline
\end{tabular}

Analysis of the thesis and dissertations listed in Table 2 show that four of them have interdisciplinarity as keyword, investigated in the context of education, with a focus on the teacher training process and on pedagogical practice. Although work T3 does not list any keywords, it meets the objective of our research.

Works T1, T4, T5 highlight the polysemous nature of the term interdisciplinary and the need to understand the terms multidisciplinary, pluridisciplinary, interdisciplinary, and transdisciplinary. In all the works, the researchers emphasize that the history of interdisciplinarity and the beginning of the studies on this topic are important to understand the current state of affairs.

Reading of the four dissertations and thesis allows one to realize that the adoption of an interdisciplinary posture is necessary to achieve a pedagogical practice that is committed to overcoming the fragmentation of knowledge.

The need to change from a fragmented to a collaborative conception is noteworthy, and dealing with interdisciplinarity in teacher training courses is mandatory. The importance of communication between disciplines must be stressed in order to break with the fragmentation of knowledge and to provide students with a holistic view of the world, new connections between theory and practice, and interdisciplinary action, which all depend on teacher's commitment. 
Table 3. Methodologies and instruments for data collection

\begin{tabular}{lll}
\hline Work & Methodology & Instruments for data collection \\
\hline T1 & Ethnographic research & Fieldwork laptop, audio recordings, semi-structured interviews \\
\hline T2 & $\begin{array}{l}\text { Exploratory research with case } \\
\text { study }\end{array}$ & $\begin{array}{l}\text { Semi-structured interview and documental analysis } \\
\text { T3 }\end{array}$ \\
\hline Status of knowledge & $\begin{array}{l}\text { Dissertations retrieved during a search of the Digital Library of the Pontificia Universidade } \\
\text { Católica do Rio Grande do Sul }\end{array}$ \\
\hline T4 & Phenomenological research & $\begin{array}{l}\text { Ecological insertion (Bioecological Theory) based on Bronfenbrenner (1996, 2011), selected } \\
\text { texts. }\end{array}$ \\
\hline T5 & $\begin{array}{l}\text { Exploratory research with case } \\
\text { study }\end{array}$ & $\begin{array}{l}\text { Questionnaire, semi-structured interviews, documental analysis, text production, and } \\
\text { videorecording of the lessons. }\end{array}$ \\
\hline
\end{tabular}

On the basis of our investigation of the works listed in Table 3, we found that the methodological path followed by the selected dissertations and thesis corresponded to qualitative research with "rich in description of people, places, and conversations" (Bogdan \& Biklen, 1994, p. 16). One of the works was designed from an ethnographic methodological perspective, two of the works consisted of a case study, one adopted a phenomenological perspective, and one was based on a study of the status of knowledge and used discursive textual analysis.

The instruments employed for data collection included fieldwork notebooks, audio recordings, semi-structured interviews, video recordings, and questionnaires. More than one instrument was used in the same work. Semi-structured interviews were the most often employed; they were used in three works. According to Bogdan $\&$ Biklen (1994), interviews are a central strategy in qualitative investigation.

Taken all the findings together, although interdisciplinarity has been much debated, there is a scarcity of recent publications about interdisciplinarity related to teacher training and teaching practice within the Brazilian context, at least during the period analyzed herein. The richness of interdisciplinarity goes beyond the epistemiological, theoretical, methodological, and didactic spheres. Adoption of interdisciplinarity in schools fosters dialogue and requires discussions and reflections within the academic environment where teachers' should seek communication between curricular components.

According to Fazenda (1994), for interdisciplinarity to be introduced in the school routine, a deep transformation of pedagogy, a new type of teacher training, and new ways of teaching are necessary. We hope that our results will motivate Brazilian teachers and researchers to investigate this topic further both in the academic environment and during teaching practices.

\section{Final Considerations}

The process of constructing the interdisciplinary approach is difficult because it may involve different contents, disciplines and people (students and teachers) and practices, including those contained in the dissertations and theses raised here.

In this context, this article is justified because it seeks to raise what has been produced within a contextualized and interdisciplinary approach to the concepts, breaking with the disciplinary stigma that 'haunts' and 'mutilates' the broad understanding of aspects of nature, once that it is not fragmented. So, interdisciplinary didactic approaches are expected to bring social impact by bringing to the school community aspects of science present in the most immediate daily life.

Thus, the education that is sought with interdisciplinarity is characterized as participatory and transformative, whose purpose is to develop in the individual and in the group the capacity to critically analyze reality, to decide joint actions to solve problems and modify situations, to organize and take action, and evaluate it critically.

Educational action does not only involve the transformation of knowledge, but also the transformation of the subjects of the process, both academics and non-academics. Interdisciplinarity, as a way of interaction between knowledges, is an element capable of operationalizing theory and practice. They configure exchanges between areas of knowledge, interaction of models and complementary concepts, as well as the integration of methodologies, instruments and techniques for a theoretical and operational consistency that structures the collective work.

Given the panorama presented, the formative possibilities provided by interdisciplinarity, with its objectives and structuring forms, seek the formation of students committed to this educational project and with the competence 
to carry it out with quality and social responsibility. In view of this training horizon, it is an important action to facilitate the diffusion and multidimensional dialogue of knowledge, considering the interdisciplinarity so that, in the process experienced by the participants, it is possible to articulate the complex dimensions of the educational process, especially those involving:

- Theory/practice: as spaces for research, re-elaboration, reinvention, creation. There is no practice unrelated to knowledge. All human actions are related to an intellectual work: it requires of the subject the activity of thinking and feeling.

- University/Community Relationship: University and community are times/spaces for construction and evaluation of knowledge. Seeking to overcome the perspective that school is the place of theory and community is the place of application/transformation. The University as mediation to learn to formulate ways of thinking/feeling/acting, not to replace previous forms, but to transform them. Without valuing prior knowledge there is no possibility of reconstruction of knowledge/practices.

- Contents: It is not only in the academic. He is not the only one responsible for the knowledge to be built. From this perspective, it requires the construction of interdisciplinary teams that favor articulations discussed in more collective situations.

Finally, it is intended to develop, from the specificity of the questions related to interdisciplinarity, a proposal of formation that articulates the knowledge of the experience with the knowledge produced in the different areas of scientific knowledge.

Therefore, an educational project is seen that articulates with the social and training projects, which creates a direct connection between formation and production, between education and political commitment. Thus, the most articulate movements between theory and practice are also contemplated in the interdisciplinarity assumptions, since this approach instigates and demands a reflexive stance that validates certain theoretical principles, confronting them with the adequacy of explanatory hypotheses to the different socio-historical contexts experienced school communities. Contributing to the construction of a reflexive attitude is one of the main goals of an interdisciplinary proposal and, in this direction, the organization of a dynamic work among teachers, academics and community is fundamental for the success of the interdisciplinary approach.

\section{References}

BDTD. (2016). Brazilian Digital Library of Theses and Dissertations. Retrieved from http://bdtd.ibict.br/vufind

Bogdan, R. C., \& Biklen, S. K. (1994). Investigação qualitativa em educação: Uma introdução à teoria e aos métodos. Porto, Portugal: Porto Editora.

Brasil. (2000). Parâmetros Curriculares Nacionais: Ensino Médio. Brasília, DF, Brazil: Ministério da Educação. Retrieved from http://portal.mec.gov.br/seb/arquivos/pdf/blegais.pdf

Cordeiro, E. O. (2012). Dissertações focalizando a interdisciplinaridade no programa de pós-graduação em educação em ciências e matemática da PUCRS: Relações entre teoria e prática (Unpublished masters dissertation). Pontifícia Universidade Católica do Rio Grande do Sul, Porto Alegre, Brazil. Retrieved from Retrieved from http://hdl.handle.net/10923/3024

Costa, D. C. (2012). A atitude interdisciplinar docente e o desenvolvimento humano: Foco no ensino médio de uma escola pública (Unpublished masters dissertation). Universidade de Taubaté, Taubaté, SP, Brazil. Retrieved from http://www.bdtd.unitau.br/tedesimplificado/tde_busca/arquivo.php?codArquivo=645

Fazenda, I. C. A. (1979). Integração e interdisciplinaridade no ensino brasileiro: Efetividade ou ideologia. São Paulo, Brazil: Loyola.

Fazenda, I. C. A. (1994). Interdisciplinaridade: História, teoria e pesquisa (4th ed.). Campinas, SP, Brazil: Papirus.

Fazenda, I. C. A. (2008). Interdisciplinaridade-transdisciplinaridade: visões culturais e epistemológicas. In Fazenda, I. C. A. (Ed.), O que é interdisciplinaridade? (pp. 17-28). São Paulo, Brazil: Cortez.

Freire, L. A. (2011). O desenvolvimento da compreensão interdisciplinar discente em cursos de formação de professores: construção de significados e sentidos (Unpublished masters dissertation). Universidade Federal do Ceará, Fortaleza, Brazil. Retrieved from http://www.repositorio.ufc.br/handle/riufc/3376

Gadotti, M. (1999). Interdisciplinaridade: Atitude e método. São Paulo, Brazil: Instituto Paulo Freire, Universidade de São Paulo. Retrieved https://xa.yimg.com/kq/groups/24693043/1074035478/name/Interdisci_Atitude_Metodo_1999.pdf 
Gerhard, A. C., \& Rocha Filho, J. B. (2012, March). A fragmentação dos saberes na educação científica escolar na percepção de professores de uma escola de ensino médio. Investigações em Ensino de Ciências, 17(1), 125-45. Porto Alegre, Brazil. from https://www.if.ufrgs.br/cref/ojs/index.php/ienci/article/view/210/144

Japiassu, H. (1976). Interdisciplinaridade e patologia do saber. Rio de Janeiro, Brazil: Imago.

Lück, H. (1997). Pedagogia da interdisciplinaridade: Fundamentos teórico-metodológicos. Petrópolis, RJ, Brazil: Vozes.

Paviani, J. (2008). Interdisciplinaridade: Conceitos e distinções (2nd ed. rev.). Caxias do Sul, RS, Brazil: Editora da Universidade de Caxias do Sul.

Pignata, E. K. A. (2011). Interdisciplinaridade no contexto do curso de pedagogia: Pertinência das concepções e ações (Unpublished masters dissertation). Universidade Católica de Brasília, Brasília, DF, Brazil. Retrieved from https://bdtd.ucb.br:8443/jspui/handle/123456789/656

Rocha Filho, J. B., Borges, R., \& Basso, N. R. S. (2007). Transdisciplinaridade: A natureza intima da educação científica. Porto Alegre, Brazil: Editora Universitária da Pontifícia Universidade Católica do Rio Grande do Sul.

Rochefort Neto, O. I. (2013). Interdisciplinaridade escolar: Um caminho possivel (Unpublished doctoral thesis). Universidade Federal do Rio Grande do Sul, Porto Alegre, Brazil. Retrieved from http://hdl.handle.net/10183/78771

Santomé, J. T. (1998). Globalização e interdisciplinaridade: O currículo integrado. Porto Alegre, Brazil: Artmed.

Trindade, D. F. (2008). Interdisciplinaridade: um novo olhar sobre as ciências. In Fazenda, I. C. A. (Ed.). O que é interdisciplinaridade? (pp. 65-83). São Paulo, Brazil: Cortez.

\section{Copyrights}

Copyright for this article is retained by the author(s), with first publication rights granted to the journal.

This is an open-access article distributed under the terms and conditions of the Creative Commons Attribution license (http://creativecommons.org/licenses/by/4.0/). 